\title{
IMPLEMENTASI KEBIJAKAN PEMBANGUNAN KELEMBAGAAN PEMERINTAH KECAMATAN SEBAGAI PERANGKAT DAERAH (Studi di Kota Kupang dan Kabupaten Sikka)
}

\author{
Leonardus Lelo, David B. W. Pandie, Lenny Tamunu \\ Program M agister IImu A dministrasi U niversitas N usa Cendana
}

\begin{abstract}
ABSTRAK
Penelitian ini bertujuan: menggambarkan implementasi kebijakan pembangunan kelembagaan pemerintah kecamatan, dan menganalisis efektif atau tidaknya implementasi kebijakan, serta faktor-faktor yang mendukung implementasi kebijakan yang ada. Metode penelitian yang digunakan adalah metode kualitatif. Fokus penelitian meliputi pelimpahan kewenangan kepada Camat; karakteristik wilayah kecamatan; dan indikator ekonomi makro yang meliputi keadaan PDRB; struktur ekonomi; dan kondisi kemiskinan masyarakat. Instrumen penelitian yang digunakan adalah wawancara dan dokumentasi. Hasil penelitian menunjukkan bahwa pelimpahan sebagian kewenangan dari Bupati Sikka dan Walikota Kupang kepada kecamatan belum berjalan efektif. Faktor penyebabnya adalah isi kebijakan yang bersifat umum atau tidak bersifat konkrit sesuai dengan karakteristik wilayah kecamatan dan beban kerja kecamatan. Selain itu faktor-faktor yang pendukung lainnya adalah faktor sumberdaya manusia, faktor prasarana/sarana dan faktor dukungan anggaran yang rasional belum sesuai dengan kebutuhan dan beban kerja kecamatan masing-masing.
\end{abstract}

Kata Kunci: Implementasi kebijakan publik, pembangunan kelembagaan pemerintah kecamatan

\section{PENDAHULUAN}

Desentralisasi kewenangan mesti dijalankan pada setiap tingkatan pemerintahan berdasarkan kebijakan atau peraturan perundang-undangan yang berlaku. Kebijakan otonomi daerah memberikan harapan baru bagi efektifitas dan efisiensi penyelenggaraan pemerintahan dengan asumsi bahwa akan memberikan kontribusi positif bagi pemerintah daerah dalam meningkatkan fungsi pelayanan, pemerdayaan dan pembangunan. Kebijakan yang lahir memberikan gambaran tentang pendekatan atau model pengembangan kelembagaan pada setiap tingkatan pemerintahan dalam melaksanakan fungsi, tugas dan kewenangan yang dimiliki. Model kelembagaan akan sangat mempengaruhi keberhasilan pemerintah dalam melaksanakan fungsi, tugas dan wewenang yang ada. Sehingga setiap kebijakan akan memberikan model atau pendekatan kelembagaan yang berbeda-beda sesuai dengan tuntutan lingkungan internal maupun tuntutan lingkungan eksternal atau tuntutan kebutuhan masyarakat.

$$
\text { Organisasi pemerintahan }
$$

diciptakan untuk memberikan pelayanan kepada masyarakat, oleh karenanya diperlukan berbagai sumberdaya menjalankan urusan pemerintahan, baik urusan wajib maupun urusan pilihan. U rusan Pemerintahan tersebut dilaksanakan oleh 5 (lima) unsur Organisasi Pemerintah Daerah yakni unsur pimpinan (Kepala Daerah dan Wakil Kepala Daerah), unsur staf (Sekretariat Daerah), unsur lini (Dinas-dinas Daerah), unsur Lembaga Teknis Daerah (Badan dan 
Kantor) serta unsur kewilayahan (K ecamatan dan K elurahan).

Undang-U ndang Nomor 32 Tahun 2004 sebagai pengganti Undang-Undang Nomor 22 Tahun 1999 tentang Pemerintahan Daerah bahwa kecamatan dibentuk di wilayah kabupaten/kota dengan Peraturan Daerah (Perda) berpedoman pada Peraturan Pemerintah (PP). Kecamatan yang dipimpin oleh seorang Camat yang dalam melaksanakan tugasnya memperoleh pelimpahan sebagian wewenang Bupati/W alikota untuk menangani sebagian urusan otonomi daerah. Selain melaksanakan tugas tersebut, Camat juga bertugas menyelenggarakan tugas umum pemerintahan yang meliputi pengawasan, koordinasi serta kewenangan residu.

Pentingnya pelimpahan wewenang dari Bupati Kepala Daerah sangat penting untuk mendorong percepatan pembangunan mengingat cakupan luasnya wilayah/K ota. M emperkecil luas wilayah secara tidak langsung memperpendek jangkauan atau jarak pelayanan kepada rakyat. Formulasi kebijakan mempengaruhi efektif atau tidaknya pelaksanaan kewenangan dari setiap tingkatan pemerintahan berdasarkan struktur dan fungsi yang diembannya. Wasistiono (2009: 48), mengatakan bahwa kewenangan yang dijalankan oleh Camat, dapat dibedakan antara kewenangan atributif dan kewenangan delegatif. Dengan demikian dapat dikatakan bahwa ada dua pandangan, yakni: 1) Camat praktis tidak lagi mampu menjalankan fungsi dengan baik, karena Camat tidak dapat mengambil keputusan-keputusan strategis yang berkaitan dengan kepentingan publik karena dapat menimbulkan implikasi hukum yang melemahkan posisi Camat; 2) Di dalam pemerintahan tidak boleh ada kekosongan kekuasaan. A pabila belum ada ketentuan yang baru, maka ketentuan yang lama masih dapat digunakan, yang terpenting pelayanan kepada rakyat tidak terlantar (prinsip mengutamakan kepentingan umum atau solus populi suprema lex).

Pemerintah Kecamatan sebagai Perangkat Daerah yang menjalankan sebagian kewenangan yang dilimpahkan oleh Bupati Kepala Daerah. Perubahan regulasi dari waktu ke waktu belum mencerminkan adanya "political will" dari pemerintah untuk memberikan kekuasaan atau kewenangan agar pemerintahan kecamatan secara kelembagaan dapat mengatur dan mengelola sebagaian kewenangan yang tertuang di dalam peraturan perundang-undangan yang berlaku.

Permasalahan ini tergambar pada setiap regulasi yang dibuat dan dampaknya terhadap implementasi kewenangan Camat sebagai koordinator penyelenggaraan pemerintahan di wilayah kecamatan, berada di bawah dan bertanggung jawab kepada Bupati melalui Sekretaris Daerah. Perangkat Daerah Kabupaten yang mengepalai wilayah kecamatan. Fenomena kelembagaan Pemerintahan Kecamatan, dengan tugas Camat "melaksanakan kewenangan pemerintahan yang dilimpahkan oleh Bupati untuk menangani sebagian urusan otonomi daerah", Pasal 3 (ayat 2) Perda Kabupaten Sikka N omor 7 Tahun 2011 tentang Organisasi dan Tata Kerja Kecamatan dan Kelurahan. Selanjutnya diatur dalam Peraturan Bupati Sikka Nomor 10 Tahun 2014 tentang Pelimphan Kewenangan Pemerintahan K epada Camat.

Pada tahun 2008-2013 Bupati Sikka mengeluarkan Peraturan B upati yang memberikan kewenangan kepada Pemerintahan Kecamatan melalui Camat untuk mengelola sebagain kewenangan disertai dengan pembiayaan sebesar $\mathrm{Rp}$ 3.000.000.000, namun dengan kepemimpinan Bupati yang baru periode $2013 \leftarrow 2018$ telah meniadakan penyerahan sejumlah anggaran dari APBD Kabupaten Sikka untuk dikelola oleh Pemerintah Kecamatan.

Peneliti melakukan penelitian tentang "Pelimpahan Sebagian Kewenangan 
Pemerintahan dari Bupati/Walikota kepada Camat baik di Kota Kupang maupun di Kabupaten Sikka didasari pemikiran bahwa sesungguhnya bertujuan untuk mengefektifkan dan mengefisienkan penyelenggaraan pemerintahan, pelayanan publik dan pemberdayaan masyarakat Desa/K elurahan. Selain itu peneliti mengamati bahwa sesungguhnya regulasi, yakni U ndang-Undang Nomor 23 Tahun 2014 telah memberi ruang kepada Daerah $\mathrm{K}$ abupaten/K ota untuk menata organisasi Kecamatan sesuai dengan kebutuhan daerah masing-masing, namun sesungguhnya realitas menunjukkan belum adanya kemauan politik dari Kepala Daerah dan DPRD K abupaten/K ota dalam merumuskan kebijakan di daerah masingmasing dalam bentuk Peraturan Daerah (Perda) dan Peraturan/K eputusan B upati/W alikota berdasarkan kondisi daerah masing-masing.

\section{KAJIAN TEORI}

\section{Implementasi Kebijakan}

Implementasi yang tidak berhasil biasanya terjadi ketika suatu kebijakan tertentu telah dilaksanakan sesuai dengan rencana, namun mengingat kondisi eksternal ternyata tidak menguntungkan, misalnya: tiba-tiba terjadi peristiwa pergantian kekuasaan (coup de'tat), bencana alam, dan Iain sebagainya. Kebijakan tersebut tidak berhasil mewujudkan dampak atau hasil akhir yang dikehendaki. Kebijakan yang memiliki resiko gagal itu disebabkan oleh faktor: pelaksanaannya yang jelek (bad execution), kebijakannya sendiri memang jelek (bad policy), kebijakan itu memang bernasib jelek (bad luck). Selain itu, persoalan utama dari desain kebijakan ialah kemampuan untuk memprediksi keadaan dimasa yang akan datang yang belum sepenuhnya berjalan dengan cukup baik (deL eon and deL eon, 2003, 475-476).

U kuran keberhasilan maupun kegagalan dari suatu kebijakan sebagian besar ditentukan dari implementasi kebijakan, sebagaiman dikemukakan oleh
Nugroho (2008:501); rencana adalah 20\% keberhasilan, implementasi adalah 60\% sisanya, 20\% sisanya adalah bagaimana kita mengendalikan implementasi. Implementasi kebijakan adalah hal yang paling berat, karena di sini masalahmasalah yang kadang tidak dijumpai dalam konsep muncul di lapangan. Selain itu, ancaman utama, adalah konsistensi implementasi.

Implementasi adalah suatu rangkaian aktifitas dalam rangka menghantarkan kebijakan kepada masyarakat sehingga kebijakan tersebut dapat membawa hasil sebagaimana yang diharapkan (Gaffar, 2009: 295). Rangkaian kegiatan tersebut mencakup persiapan seperangkat peraturan Ianjutan yang merupakan interpretasi dari kebijkan tersebut. M isalnya dari sebuah undangundang muncul sejumlah peraturan pemerintah, keputusan presiden, maupun peraturan daerah, menyiapkan sumber daya guna menggerakan implementasi termasuk di dalamanya saran dan prasarana, sumber daya keungan, dan tentu saja siapa yang bertanggung jawab melaksanakan kebijakan tersebut, dan bagaimana mengantrakan kebijakan secara konkrit ke masyarakat.

Mazmania dan Sabaiter (1979) dalam Wahab (1997:65) menjelaskan makna implementasi ini dengan mengatakan bahwa memahami apa yang senyatanya terjadi sesudah suatau program dinyatakan berlaku atau dirumuskan merupakan fokus perhatian implementasi kebijaksanaan, yakni kejadian-kejadian dan kegiatan-kegiatan yang timbul sesudah disahkan pedoman-pedoman kebijaksanaan Negara, yang mencakup baik usaha-usaha untuk mengadministrasikannya maupun untuk menimbulkan akibat atau dampak nyata pada masyarakat atau kejadiankejadian.

\section{Pembangunan Kelembagaan \\ Kecamatan}

Wasistiono (2009: 48) mengatakan bahwa kewenangan yang dijalankan oleh 
Camat, dapat dibedakan antara kewenangan atributif dan kewenangan delegatif. Dengan demikian dapat dikatakan bahwa ada dua pandangan, yakni: (1) Camat paraktis tidak lagi mampu menjalankan fungsi dengan baik, karena Camat tidak dapat mengambilkeputusan-keputusan strategis yang berkaitan dengan kepentingan publik karena dapat menimbulkan implikasi hukum yang melemahkan posisi Camat; (2) Di dalam pemerintahan tidak boleh ada kekosongan kekuasaan, dengan demikian apabila belum ada ketentuan yang baru, maka ketentuan yang lama masih dapat digunakan, yang terpenting pelayanan kepada rakyat tidak terlantar (prinsip mengutamakan kepentingan umm atau solus populi suprema lex).

Tugas umum pemerintah dalam Undang-U ndang Nomor 32 Tahun 2004 dan hasil revisi UU Nomor 12 Tahun 2008 tentang Pemerintahan Daerah dan Peraturan Pemerintah Nomor 19 Tahun 2008, menjelaskan bahwa Kecamatan merupakan perangkat daerah kabupaten/kota sebagai pelaksana teknis kewilayahan yang mempunyai wilayah kerja tertentu dan dipimpin oleh Camat (pasal 14, ayat 1). Camat menyelenggarakan tugas umum pemerintahan (pasal 15, ayat 2) yang meliputi: a) mengkoordinasikan kegiatan pemberdayaan masyarakat; b) mengkoordinasikan upaya penyelenggaraan ketenteraman umum; c) mengkoordinasikan penerapan dan penegakak peraturan perundangundangan; d) mengkoordinasikan pemeliharaan prasarana dan fasilitas pelayanan umum; (e) mengkoordinasikan penyelenggaraan kegiatan pemerintahan di tingkat kecamatan; (f) membina penyelenggaraan pemerintahan desa/dan/atau kelurahan; dan (g) melaksanakan pelayanan masyarakat yang menjadi ruang lingkup tugasnya dab/atau yang belum dapat dilaksanakan pemerintahan desa atau kelurahan.
Selain tugas pemerintahan umum, Camat juga melaksanakan kewenangan pemerintahan yang dilimpahkan oleh B upati/Walikota untuk menangani sebagian urusan otonomi daerah, yang meliputi aspek: (a) perizinan; (b) rekomendasi; $\quad$ (c) koordinasi; (d) pembinaan; (e) pengawasan; (f) fasulitasi; (g) penetapan; (h) penyelenggaraan; dan (i) kewenangan lain yang dilimpahkan.

Susunan organisasi, Peraturan Pemerintah Nomor 19 Tahun 2008 pada pasal 23, menjelaskan : (1) Organisasi kecamatan terdiri dari 1 (satu) sekretaris, paling banyak 5 (lima) seksi, dan secretariat membawakan paling banyak 3 (tiga) sub bagian; (2) seksi paling sedikit meliputi: seksi tata perintahan; seksi pemberdayaan masyarakat dan desa; dan seksi ketenteraman dan ketertiban umum. Struktur organisasi kecamatan yang ditetapkan oleh jika kita berpedoman pada karakteristik dan beban kerja kecamatan atau dengan kata lain tipologi seyogyanya pasti berbeda-beda jumlahnya, namun tergantung pada political will dari kepala daerah dan DPRD dalam menetapkan Perda tentang struktur organisasi dan tata kerja kecamatan.

Perencanaan kecamatan dalam Peraturan Pemerintah Nomor 19 tahun 2008, menjelaskan bahwa: 1) Dalam rangka penyelenggaraan pemerintahandi kecamatan, disusun perencanaan pembangunan sebagai kelanjutan dari hasil Musyawarah Perencanaan Pembangunan Desa/ Kelurahan; 2) Perencanaan pembangunan kecamatan merupakan bagian dari perencanaan pembangunan kabupaten/kota; 3) Perencanaan pembangunan kecamatan sebagaimana dimaksud pada ayat (1) dilakukan melalui Musyawarah Perencanaan Pembangunan Kecamatan secara partisipatif; (4) M ekanisme penyusunan rencana pembangunan kecamatan sebagaimana dimaksud pada ayat (3) berpedoman pada Permendagri. Untuk mendukung keberhasilan atau kinerja pemerintah kecamatan 
diperlukan anggaran yang dikelola oleh kecamatan sebagai Satuan Kerja Perangkat Daerah (SK PD. Pada pasal 30 Peraturan Pemerintah Nomor 19 tahun 2008 berbunyi sebagai berikut: (ayat 1). Kecamatan sebagai satuan kerja perangkat daerah menyusun rencana anggaran satuan kerja perangkat daerah sesuai dengan peraturan perundangundangan; (ayat 2) Rencana anggaran satuan kerja perangkat daerah kecamatan sebagaimana dimaksud pada ayat (1) disusun berdasarkan rencana kerja kecamatan; (ayat 3) Rencana kerja kecamatan sebagaimana dimaksud pada ayat (2) disusun berdasarkan rencana strategis kecamatan.

Perangkat Daerah K abupaten/K ota salah satunya adalah Kecamatan. Kecamatan dipimpin oleh seorang kepala yang disebut Camat. Undang-Undang Nomor 23 Tahun 2014 dan Peraturan Pemerintah Nomor 19 Tahun 2008, memberikan ketegasan bahwa kewenangan $\mathrm{C}$ amat yang berada di bawah dan bertanggung jawab kepada Bupati/W alikota melalui sekretaris Daerah. Camat mempunyai Tugas sesuai berdasarkan pasal 225 ayat (1) sebagai berikut :

a. M enyelenggarakan urusan pemerintahan umum sebagaimana dimaksud dalam pasal 25 ayat (6);

b. Mengkoordinasikan kegiatan pemberdayaan masyarakat;

c. Mengkoordinasikan upaya penyelenggaraan ketenteraman dan ketertiban umum:

d. M engkoordinasikan penerapan dan penegakan Perda dan Perkada;

e. Mengkoordinasikan pemeliharaan prasarana dketentuan an sarana pelayanan umum;

f. M engkoordinasikan penyelenggaraan kegiatan pemerintahan yang dilakukan oleh perangkat Daerah di K ecamatan;

g. Membina dan mengawasi penyelenggaraan kegiatan Desa dan/atau kelurahan; h. M elaksanakan urusan Pemerintahan yang menjadi kewenangan Daerah K abupaten/K ota yang tidak dilaksanakan oleh unit kerja Perangkat Daerah kabupaten/kota yang ada di Kecamatan; dan

i. Melaksanakan tugas Iain sesuai dengan ketentuan peraturan perundang-undangan.

Camat mendapatkan pelimpahan sebagian kewenangan Bupati/Walikota untuk melaksanakan sebagian Urusan Pemerintahan yang menjadi kewenangan daerah Kabupaten/K ota. Pelimpahan Kewenangan Bupati/Walikota dilakukan berdasarkan pemetaan pelayanan publik yang sesuai dengan karakteristik K ecamatan dan/atau kebutuhan masyarakat pada Kecamatan yang bersangkutan. Pelimpahan kewenangan Bupati/W alikota sebagaimana dimaksud ditetapkan dengan keputusan Bupati/Walikota berpedoman pada Peraturan Pemerintah. Pendanaan dalam penyelenggaraan tugas pemerintahan yang dilakukan oleh Camat dibebankan pada A PBD K abupaten/K ota. Daerah K abupaten/K ota membentuk Kecamatan dalam rangka meningkatkan koordinasipenyelenggaraan pemerintahan, pelayanan publik, dan pemberdayaan masyarakat Desa/K elurahan. (UU No.23 Tahun 2014 pasal 221 ayat 1 ). Selanjutnya pada pasal 223 ayat 1 dan 2, menyebutkan bahwa kecamatan diklasifikasikan atas: Kecamatan Tipe A yang dibentuk untuk K ecamatan dengan beban kerja yang besar (ayat 1); dan Kecamatan tipe B yang dibentuk untuk Kecamatan dengan beban kerja yang kecil. Penetapan beban kerja K ecamatan didasarkan pada jumlah penduduk, Iuas wilayah, dan jumlah Desa/K elurahan (ayat 2).

\section{METODE PENELITIAN}

Penelitian yang digunakan adalah deskriptif kualitatif, dengan pertimbangan bahwa metode ini cocok untuk pendekatan 
penelitian yang bersifat studi kasus. Adapun informan dalam penelitian ini adalah: Bupati/Walikota, DPRD sebanyak 2 orang, sekretaris daaerah, K epala bagian pemerintahan, camat sebanyak 3 orang, dan kepala seksi sebanyak 2 orang. Teknik analisis data utama yang digunakan adalah sebagaimana yang dikemukan oleh Miles dan Huberman mencakup tahapan-tahapan seperti data reduction, display, dan verification. Miles dan Haberman dalam Bungin (2001 : 99), menjelaskan bahwa analisis data dalam penelitian berlangsung bersamaan dengan proses pengumpulan data melalui tiga tahap model air, yaitu reduksi data, penyajian data dan verifikasi. Namun, ketiga tahapan tersebut berlangsung secara simultan.

\section{HASIL DAN PEMBAHASAN}

\section{Implementasi Kebijakan}

Undang-undang nomor 32 tahun 2004 pada pasal 126 ayat 1 menyatakan bahwa kecamatan dibentuk di Wilayah Kabupaten/K ota dengan Perda berpedoman pada Peraturan Pemerintah, A yat 2, kecamatan sebagaimana dimaksud ayat 1 dipimpin oleh Camat yang dalam pelaksanaan tugasnya memperoleh pelimpahan sebagian wewenang Bupati atau Walikota untuk menangani sebagian urusan Otonomi Daerah.

M enurut Sobandi, secara teoritisnormatif kewenangan dapat dibedakan menjadi 2, yaitu kewenangan delegatif dan atributif. Kewenangan atributif adalah kewenangan yang melekat dan diberikan pada institusi atau pejabat berdasarkan peraturan perundang-undangan, sedangkan kewenangan delegatif adalah kewenangan yang berasal dari instansi atau pejabat di atasnya.

Pola seragam untuk semua kabupaten dalam pelimpahan wewenang yang dilimpahkan oleh Bupati/Walikota, jenis-jenis kewenangan yang dapat didelegasikan kepada Camat adalah: 1) Kewenangan Perijinan; 2) Kewenangan
R ekomendasi; 3) K ewenangan K oordinasi; 4) Kewenangan Pembinaan; 5) Kewenangan Pengawasan; 6) Kewenangan Fasilitasi; 7) Kewenangan Penetapan; 8) Kewenangan Pengumpulan data dan penyampaian informasi; 9) Kewenangan Penyelenggaraan kegiatan pelayanan masyarakat.

Tugas umum pemerintahan adalah: 1) M engkoordinasi kegiatan pemberdayaan masyarakat, 2) koordinasi penyelenggaraan ketertiban dan ketentraman umum 3) koordinasi penerapan dan penegakkan peraturan perundang-undangan, 4) koordinasi pemeliharaan prasarana dan fasilitas umum, 5) koordinasi penyelenggaraan kegiatan pemerintahan ditingkat kecamatan, 6) membina penyelenggraan pemerintahan desa dan/atau kelurahan dan 7) Melaksanakan pelayanan masyarakat yang menjadi ruang lingkup tugasnya dan/atau yang belum dilaksanakan pemerintah desa atau kelurahan.

\section{Pelimpahan Kewenangan dari Bupati/Walikota kepada Camat}

Perspektif administrasi publik, pelimpahan kewenangan dari B upati/Walikota kepada Camat, dan dari Camat kepada K elurahan ini bukan hanya sebuah kebutuhan, namun lebih merupakan suatu keharusan untuk mencapai suatu efektivitas dan efisiensi penyelenggaraan pemerintahan, sekaligus meingkatkan kualitas pelayanan umum di daerah-daerah (U tomo, 2004).

Untuk mempercepat terwujudnya kesejahteraan masyarakat melalui peningkatan pelayanan, pemberdayaan serta peran masyarakatnya adalah dengan menempatkan institusi kecamatan sebagai unit pelayanan terdepan.

$$
\text { Pendelegasian sebagian }
$$

kewenangan pemerintahan dari Bupati/Walikota kepada camat dilakukan dengan menerbitkan Surat Keputusan B upati/Walikota, bukan dengan Peraturan Daerah. Pertimbangannya adalah bahwa 
yang didelegasikan adalah kewenangan pejabat (Bupati/Walikota) kepada pejabat bawahannya (camat).

Pelimpahan sebagian wewenang bupati/walikota kepada Camat dilingkungan $\mathrm{K}$ ota $\mathrm{K}$ upang diatur melalui Peraturan Walikota Kupang Nomor 17 Tahun 2012, tanggal 14 Desember 2012, dengan kewenangan yang dilimpahkan sebanyak 20 bidang. Sedangkan pelimpahan sebagian wewenang bupati Sikka kepada camat diatur dalam Peraturan B upati Sikka Nomor.10 Tahun 2014, tanggal 3 Juli 2014, dengan kewenangan yang dilimpahkan sebanyak 34 bidang.

\section{Faktor Pendukung Implementasi}

\section{Struktur Organisasi}

Faktor pendukung implementasi kewenangan adalah struktur organisasi. Struktur organisas dipandang penting karena akan terlihat dengan jelas wewenang, pembagian tugas dan fungsi pokok camatdan aparat lainnya dibawah camat. Struktur organisasi dan tata kerja kecamatan kota K upang sesuai perda K ota K upang No.08 tahun 2008 terdiri atas, 1) Camat mengepalai dan memimpin sekretaris dan jabatan fungsional, 2) sekretaris memimpin para kasubag perencanaan, evaluasi dan pelaporan, umum dan kepegawaian dan keuangan serta perlengkapan dibawah kasubag terdapat kepala seksi pemerintahan, kepala seksi ketentraman dan ketertiban, kepala seksi pemberdayaan masyarakat, kepala seksi pendidikan dan kepala seksi kesehatan. Struktur organisasi dan tata kerja kecamatan kabupaten Sikka sesuai perda kabupaten Sikka no.7 tahun 2011 terdiri atas Camat, memimpin sekreariat dan kelompok jabatan fungsional. pada sekretariat memiliki sub bagian program, keuangan, evaluasi dan pelaporan serta sub bagian umum, kepegawaian dan perlengkapan. Selanjutnya dimiliki pula sub bagian program keuangan evaluasi dan pelaporan, seksi pemberdayaan masyarakat ekonomi dan pembangunan, serta seksi kesejahteraan social.

Struktur organisasi kecamatan Kota K upang dan kecamatan kabupaten Sikka tidak memiliki perbedaan yang prinsip. Namun pada kecamatan kabupaten Sikka struktur organisasi sub bagian program keuangan, evaluasi dan pelaporan diletakkan seolah-olah sejajar dengan seksi pemberdayaan masyarakat ekonomi dan pembangunan dan seksi kesejahteraan sosial. kepegawaian, kepala sub bagian keuangan dan perlengkapan berada diatas struktur para kepala seksi.

\section{Pengelolaan Keuangan dan Sumber Daya Manusia pada Kecamatan di Kota Kupang}

Sumber daya lain yang juga penting untuk menunjang pemberdayaan peran dan fungsi camat adalah keuangan. Pendelegasian itu harus diikuti dengan penyediaan sumber dana yang cukup memadai, sesuai dengan kemampuan keuangan. Tidak ada pemberian mandate tanpa diikuti dengan pembiayaan. Tabel.4.56 berikut adalah prioritas dan program Anggaran sementara kabupaten sikka (PPAS) Tahun Anggara 2016. Anggaran yang ada digunakan untuk belanja langsung, program pelayanan administrasi perkantoran peningkatan sarana dan prasarana aparatur, penunjang pelayanan, administrasi perkantoran dan program peningkatan kedinasan kepala daerah/W alikota.

Kecamatan selaku pengguna anggaran sesuai permendagri nomor 13 tahun 2016 pada tahun anggaran 2014 dalam menyelenggarankan urusan wajib pemerintahan umum berdasarkan Dokumen pelaksanan anggran (DPA) pada pelaksanan kegiatannya di biayai dari A PBD K ota K upang, adapun Pos anggaran belanja tersebut terdiri dari belanja langsung dan belanja tidak langsung. 


\section{Analisis Pelimpahan Kewenangan Kabupaten Sikka dan Kota Kupang}

Faktor penting dalam menentukan pedelegasian kewenangan adalah karakteristik geografis (Daratan atau kepulauan, daratan atau pegunungan dan sebagainya), karakteristik penduduk (jenis pendidikan, mata pencaharian, karakteristik wilayah (perkotaan, pedesaan, perkebunan, kehutanan, perindustrian, perumahan dsb).

Di dalam Pasal 120 ayat (2) U ndangUndang N omor 32 Tahun 2004 dinyatakan bahwa "Perangkat daerah, kecamatan, dan kelurahan". Pasal tersebut menunjukkan adanya dua perubahan penting yaitu Pertama Kecamatan bukan Iagi wilayah administrasi pemerintahan dan dipersepsikan merupakan wilayah kekuasaan Camat. Dengan Paradigma baru, kecamatan merupakan suatu wilayah kerja atau areal tempat camat bekerja. Kedua, Camat adalah perangkat daerah kabupaten/kota dan bukan lagi kepala wilayah adminstrasi pemerintahan, dengan demikian camat bukan lagi penguasa tunggal yang berfungsi sebagai administrator pemerintahan, pembangunan dan kemasyarakatan, akan tetapi merupakan pelaksana sebagian wewenang yang dilimpahkan oleh B upati/W alikota.

Camat diberikan kewenangan untuk mendorong partisipasi masyarakat, membina mengawasi, serta mengevaluasi program-program pemberdayaan masyarakat dalam rangka proses perencanaan pembangunan kecamatan. Dalam Prioritas dan Program Anggaran Sementara K abupaten SIK KA, tersaji pada tabel 4.103.

Camat adalah adalah koordinator yang wajib mengkoordinasikan dan dikoordinasikan oleh perangkat pemerintahan yang ada diwilayahnya serta melakukan evaluasi terhadap penyelenggaraan pemerintahan di tingkat kecamatan.

Implementasi kewenangan dari Bupati kepada Camat di Kabupaten Sikka belum dilaksanakan dengan alasan: 1) Sesungguhnya belum ada political Will dari Bupati/Walikota berdasarkan dokumen Paraturan B upati tentang pelaksanaan pelimpahan sebagian kewenangan Bupati kepada Camat baru dikeluarkan pada tahun 2014 (terlambat waktunya karena Peraturan Pemerintah tantang kecamatan telah diterbitkan pada tahun 2008), 2) Rincian pelimpahan kewenangan belum menggambarkan keseriusan dari Bupati dalam melimpahkan kewenangan karena sifatnya umum dan implikasinya pada pelaksanaan tugas pemerintahan umum sajua, 3) RPJMD belum memuat pelimpahan kewenangan kepada Camat sebagai perangkat daerah yang menjabarkan fungsi, tugas dan K ewenangan berdasarkan Peraturan Bupati tentang peimpahan kewenangan kepada Camat yang berdampak pada penyusunan rencana kerja kecamatan dalam melaksanakan tuhas pelimpahan wewenang tersebut, sehingga dalam proses pembahasan KUA-PPAS sampai dengan penetapan perda APBD bisa terakomodir atau dengan kata lain perlu adanya revisi RPJMD Kabupaten Sikka tahun 2013 2018 , 3) Pemerintah daerah Kabupaten Sikka perlu menyiapkan perangkat pendukung implementasi kewenangan berupa: SDM baik secara kuantitas maupun kualitas agar mampu melaksanakan kewenangan apabila kewenangan yang diberikan kepada camat telah dikonkritkan, 4) Pemerintah Daerah Kabupaten Sikka juga perlu menyiapkan prasarana/sarana pendukung pelaksanaan kewenangan apabila dipandang belummampu mendukung pelaksanaan kewenangan yang ada, 5) Pemerintah Daerah Kabupaten Sikka perlu memeberikan pelatihan kepada pemerintah kecamatan dalam upaya penguatan kapasitas sumber daya manusia pegawai negeri sipil dalam mengelola administrasi pemerintahan di kecamatan melalui pendidikan dan pelatihan sesuai dengan kompentensi yang dibutuhkan. 
Untuk mensejahterakan perekonomian masyarakat terutama pada bantuan Usaha Kredit Mikro (UKM), sesuai dengan yang telah diundangkan Peraturan Presiden (Perpres) No.98 tahun 2014, tentang Perizinan untuk usaha mikro dan kecil. Dalam Perpres tersebut, terdapat kewajiban bagi pelaku usaha mikro dan kecil untuk memperoleh ijin dari Camat setempat.

Pemberian izin usaha mikro dan kecil ini bermaksud untuk memberikan kepastian hukum dan sarana pemberdayaan bagi pelaku usaha mikro da kecil dalam mengembangkan usahanya.

Pada pasal 4 Perpres tersebut menyebutkan bahwa pelaksana izin usaha mikro dan kecil adalah Camat yang mendapatkan pendelegasian kewenangan dari Bupati atau walikota. Selain Camat, izin juga bisa diberikan oleh lurah atau kepala desa tergantung dari karakteristik wilayah. Peraturan Presiden No.98 Tahun 2014.

Berdasarkan data dan hasil wawancara serta data sekunder yang diperoleh di masing-masing K abupten/K ota maka kepemimpinan yang ada yang dilihat dari jumlah personalia dengan besaran struktur dan besaran organisasi dan jumlah personalia yang ada kurang efektif, jika di sandingkan dengan besaran kewenangan yang diberikan baik kewenangan dalam penyelenggaraan tugas pemerintahan umum maupun pelimpahan sebagian kewenangan dari B upati/W alikota.

B erdasarkan data dan hasil analisis anggaran yang dialokasikan per-kecamatan baik Kota Kupang maupun Kabupaten Sikka, disimpulkan bahwa belum efektif berdasarkan besar dan luasnya cakupan kewenangan, maka alokasi anggaran belum maksimal membiayai seluruh program dan kegiatan berdasarkan kewenangan yang diberikan.

Hasil wawancara dan dukungan data sekunder Kota kupang disimpulkan bahwa Camat di Kota Kupang hanya menyelenggarakan tugas pemerintahan umum sedangkan pelimpahan sebagian kewenangan dari walikota belum dilaksanakan.

Berdasarkan hasil wawancara dan dukungan data sekunder $\mathrm{K}$ abupaten Sikka disimpulkan bahwa Camat selain menyelenggarakan tugas pemerintahan umum dan sudah mulai mengimplementasikan pelimpahan sebagian kewenangan dari bupati.

Dilihat dari struktur kelembagaan organisasi kecamatan yang ada baik di $\mathrm{K}$ ota K upang maupun di Kabupaten Sikka sesungguhnya belum efektif karena struktur atau kelembagaan organisasi kecamatan tidak sebanding dengan besar dan luasnya cakupan yang ada.

\section{SIMPULAN}

Dari penelitian yang telah dilakukan maka dapat disimpulkan bahwa:

1. Implementasi kebijakan pembangunan kelembagaan pemerintah kecamatan terutama implementasi pelimpahan sebagian kewenangan Bupati/W alikota kepada Camat baik di Kabupaten Sikka maupun di K ota $\mathrm{K}$ upang belum berjalan aktif sesuai rujukan peraturan perundangan yang ada.

2. Kebijakan pembangunan kelembagaan pemerintah kecamatan terutama pelimpahan kewenangan dari B upati/W alikota belum ef ektif.

3. Faktor-faktor yang mendukung keberhasilan implementasi kebijakan pembangunan kelembagan pemerintah kecamatan adalah : faktor sumber daya manusia, pelaksana kebijakan, faktor prasarana/sarana dan faktor keterbatasan anggaran.

\section{DAFTAR PUSTAKA}

Bungin, Burhan., 2001, Metodologi Penelitian Kualitatif, Aktualisasi Metodologis ke Arah Ragam Varian Kontemporer, Raja GrafindoPersada, J akarta 
Deleon, Peter and Linda deLeon., 2002, What Ever Happened to Policy Implementation? An Alternative Approach, J $\leftrightarrow$ PART, O ctober

Gaffar, Afan. 2009. Politik Indonesia: Transisi Menuju Demokrasi, Y ogyakarta, Cetakan V, Pustaka Pelajar.

Nugroho, Riant. 2008. Kebijakan Publik, Formulasi Implementasi dan Evaluasi Penerbit PT Alex Media Kompetindo Kelompok Gramedia J akarta.

Peraturan Pemerintah nomor 19 Tahun 2008 tentang Pemerintah Daerah

Undang-U ndang nomor 32 Tahun 2004 tentang Pemerintah D aerah

Undang-Undang nomor 22 Tahun 1999 tentang Pemerintah Daerah

Undang-U ndangNomor 23 Tahun 2014 tentang pemerintah daerah

Peraturan Bupati Sikka Nomor 10 Tahun 2014 tentang Pelimphan Kewenangan Pemerintahan Kepada Camat.

Wahab, Solichin Abdul. 1997. Analisis Kebijaksanaan dari Formulasi ke Implementasi Kebijaksanaan Negara.B umi A ksara. J akarta.

Wasistiono, Sadu, dkk. 2009. Perkembangan Organisasi

Kecamatan Dari Masa Ke Masa. Fokusmedia. B andung. 